\title{
Manuscripts are like vampires: Libraries and their uncertain histories on the island of Jerba, Tunisia
}

\author{
Paul M. Love Jr.
}

Al Akhawayn University in Ifrane

\section{Correspondence}

Paul M. Love Jr., Al Akhawayn University in Ifrane, PO Box 104, Hassan II Avenue, Ifrane 53000, Morocco.

Email: p.love@aui.ma

Funding information

Arcadia Fund, Grant/Award Numbers:

EAP1216, EAP993; The Islamic Manuscripts Association

\begin{abstract}
This article explores the methodological possibilities for using unverifiable, contradictory, or demonstrably false accounts of the past for historical research. Drawing from the methodological example of historical studies on accusations of vampirism in colonial East Africa, it presents histories of three Ibadi Muslim manuscript libraries on the island of Jerba, Tunisia. These stories contain contradictory or otherwise unverifiable elements, each of which raises methodological questions for its use as a historical source. The article argues that by drawing upon the methodological premise of these studies of vampires, historians can approach far more basic questions of historical research regarding chronology, contradictory evidence, and veracity.
\end{abstract}

\section{1 | INTRODUCTION}

What are historians to do with unverifiable or demonstrably untrue information about the past? In this article, I view this question through the lens of stories about manuscript libraries: The family used to have a large manuscript collection but at some point began secretly selling it to foreigners, book by book. Another family acquired its impressive library not through the collecting efforts of its founder but instead through a brazen act of thievery. In an especially dramatic account, a member of the family intentionally set the library ablaze, reducing one of the oldest manuscript collections on the island to a pile of ashes.

Stories like these of the destruction, concealment, theft, or other loss of manuscripts circulate widely today on the island of Jerba in southern Tunisia. An Arabic manuscript culture thrived on this Mediterranean island for centuries from the medieval era until the middle of the 20th century, resulting in the formation of dozens of family and mosque libraries. This is especially true for the island's Ibadi Muslims, a minority community in North Africa and the Arabian Peninsula that is neither Sunni nor Shii. Ibadis in Jerba have maintained family libraries housing some of the only copies of their community's texts in existence (Gaiser, 2010; Hoffman, 2012, 2015; Love, 2018; Wilkinson, 2010). 
The rumors and stories relating to the history of manuscript collections in Jerba often include unverifiable, contradictory, or demonstrably untrue details. They nevertheless convey important information for those who circulate them. For the same reason, these stories also carry tremendous potential for use as historical sources. Historians have demonstrated the ways in which rumor and gossip function as valuable sources for understanding the past (Coast \& Fox, 2015; Ghosh, 2008; White, 1994). In the case of manuscript stories in Jerba, their use by historians raises a number of methodological questions that are the focus of this article.

In what follows, I offer three exemplary histories of manuscript libraries on Jerba gathered during fieldwork between 2015 and 2019. The most recent iteration of fieldwork (2017-2019) took place within the framework of an Endangered Archives Programme (EAP) project to document and to conserve private libraries in Jerba. ${ }^{1}$ In gathering information on these collections, our team spoke informally to people from throughout the island about manuscript libraries there. The details of these stories raise methodological questions that challenge historians to adopt creative ways of understanding them as sources for the past.

In approaching these stories, I have drawn methodological inspiration from what I see as an analogous body of historical research: the study of vampire stories in other parts of Africa. Historians working on accounts and accusations of vampirism have offered remarkably creative and nuanced ways of approaching these stories and I seek to follow their methodological example in understanding these manuscripts stories in Jerba. This does not mean adopting whole-sale the approaches employed by studies of fantastical accounts of bloodsucking and applying them to library history. Rather, I seek here to highlight some elements of their methodologies that could prove fruitful for the (admittedly less fantastical) history of manuscript libraries. That is, I argue that some of the premises of these studies of vampires are useful to think with in addressing far more basic problems of historical inquiry: contradictions and inconsistencies in terms of the chronology of events, the establishment of facts and their relationships to one another, and even the very question of truth.

I begin by introducing briefly some recent scholarship surrounding accounts of vampires to demonstrate how historians have understood and used them. Drawing on what I identify as the shared premise of this literature, I then present three manuscript library histories from Jerba, highlighting their unverifiable or otherwise problematic elements and the methodological questions they raise.

\section{2 | VAMPIRE STORIES AND THEIR METHODOLOGICAL STAKES}

The "vampires" in stories from East Africa often refer to the Swahili word mumiani (White, 2000, pp. 10-14). Since most historians determined that the characters in these accounts were not vampires (i.e., they were not undead beings who consumed the blood of their victims), the next step was to explore the reasons for the creation and circulation of the stories. This meant addressing their untrue nature.

Luise White offered a powerful response. In a series of studies, White analyzed accounts of bloodsucking in colonial East Africa in the early 20th century (White, 1993, 1994, 1997, 2000). Rather than dismiss these stories or interpret them as Africans "misunderstanding" what was happening around them, she instead read them as encounters with the technologies of colonialism and approached the vampires "as an epistemological category." (White, 2000, p. 50) They were attempts to come to terms with and to make sense of those experiences, leading her to the conclusion that in relating these accounts

people do not speak with truth, with a concept of the accurate description of what they saw, to say what they mean, but they construct and repeat stories that carry the values and meanings that most forcibly get their points across. (White, 2000, p. 30)

Moreover, for White, this applied to both written and oral accounts of vampirism. In putting oral histories into conversation with archival evidence, written testimonies of colonial officials, and newspaper coverage, she 
demonstrated the complementarity of these sources; indeed, she showed that they are "inseparable." For example, White studied the 1953 trial in Kampala of a driver named Juma Kasolo, who was accused of abduction (White, 2000, pp. 242-268). While this was the formal reason for his trial, the understanding among local people was that he was an agent of vampires (here called bazimamoto). In putting oral histories of the events surrounding the trial in conversation with contemporary newspaper coverage, she demonstrated that newspapers both interpreted the details of the trial drawing on the idiom of the vampire story genre and used those stories to comment on current events. Her description of how what she describes as the "feedback from written to oral text" in this story demonstrates the interrelationship between these two types of sources:

Storytellers and newspaper readers in Kampala might each retell the Kasolo story using aspects of the oral and written versions; they elaborate on written material with oral and on the oral with the written, but one kind of source does not overwhelm the other. (White, 2000, p. 264)

Additional work on vampirism in Africa built upon White's arguments. James Brennan focused on a 1959 riot in Dar es Salaam, in which people accused police of being mumiani. He emphasized the importance of what he called "explanatory contexts" in understanding "evidence that is generally evocative but specifically elusive" (Brennan, 2008, p. 86). His emphasis on context echoes earlier work by Peter Pels, whose study of mumiani in Tanzania sought to move beyond "strictly symbolic analyses" to a more precise anthropological understanding of how context elucidates the spread of rumors (Pels, 1992, p. 181).

Zebulon Dingley examined rumors in a mumiani "panic" in coastal Kenya in 1945. He complemented previous work by arguing for a "dialectal approach" that puts content and context in conversation, forming a historical "constellation." In his reading, these stories of mumiani succeed in spreading by "drawing on a local repertoire of historical meanings and motif" (Dingley, 2018, p. 395). Addressing a different historical context, Erin Pettigrew arrived at similar conclusions about what accusations of bloodsucking in colonial Mauritania reveal about local understandings of the past and present in response to environmental changes in the Sahara (Pettigrew, 2016).

All these explanations of vampire accounts rest on the methodological assumption that regardless of the veracity of the events being described and despite elements of them remaining unverifiable or unknown, the stories themselves carry value in that they reflect local responses to change-whether social, political, environmental, or religious-and that they help people make sense of it. This suggests the powerful analytic value of historians taking untrue, implausible, or unverifiable accounts of the past seriously, even if this seems to contradict the basic tasks of a historian (Mann, 2008). Gossip, rumor, and secrets offer a window into how people in a given context reformulate their understanding of their connections with the past and the present. Rumors and panic have, for example, proved to be a powerful tool for scholarship on colonialism outside Africa (Bayly, 1999; Choudhury, 2004; Fischer-Tiné \& Whyte, 2017).

With this shared methodological assumption of approaches to vampire accounts as my guide, I now turn to three stories of libraries in Jerba.

\section{1 | Burning books (?): The al-Ba țūrī library}

One of the most popular and dramatic historical accounts of manuscript collections on the island relates to the al-Ba'țūrī family library. This collection raises the first of three methodological issues addressed here: the absence of written evidence and considerable contradiction in oral evidence.

Founded sometime in the late 18th century, the al-Ba țūrī library housed a substantial collection of manuscripts associated with the island's minority Ibadi Muslim community. The al-Ba'țūrī collection carried special importance after it was discovered that the library held a unique copy of the oldest extant work by an autochthonous Ibadi Muslim author in Northern Africa (al-Ibāḍī, 1986, pp. 41-51). A 1970 article offered a short list of other rare titles 
held in this library. The author wrote that the "collection was in disorder and folios and quires of [manuscripts] were confused; this will necessitate the hard task of classification and rearrangement" (Ennami, 1970, p. 64). In the mid-1980s, an attempt to survey of the island's manuscript libraries included the al-Batūūī collection. According to the version of the list published in 1987, the library held around 67 manuscript titles ("Qā'imat al-kutub," 1987, pp. 19-21). A member of the survey team who visited the library in the mid-1980s, the former director of the Association pour la sauvegarde de l'ile de Djerba (ASIDJ) that carried out the survey, noted in a 2017 interview that the library was in complete disarray (Farid El Cadi, personal communication, July 27, 2017).

Classification and rearrangement never came. Sometime shortly before or after the inventory of the collection was published in 1987, a fire consumed the library's manuscripts, destroying the collection in its entirety. While written sources certainly testify to its existence, no written source provides any explanation of the library's destruction. During fieldwork in Jerba in 2014-2015, 2017, and 2018, I encountered oral versions of the story that contained substantially more detail. In these accounts, a member of the family suffering from a mental illness brought on by a traumatic experience set fire to the collection. When I interviewed those close to the al-Ba țūrī family about the event, accounts differed remarkably in terms of chronology and other details of the fire's origins, ranging from it having occurred in the to the early 2000s. In some cases, the same individuals provided remarkably different dates for the fire's occurrence and details surrounding it. ${ }^{2}$

In other cases, even the event of the fire itself was contested. Instead, the story of the fire served as a clever ruse for concealing the true fate of a manuscript collection. The absence of concrete evidence for when, where, and how the fire happened generated a new rumor: There had been no fire and the family, for some unknown reason, was concealing the collection. Alternatively, some of the texts were saved but then hidden. These circumstances fostered much doubt about the veracity of the story and implied that perhaps behind these accounts lies a very different history.

What are historians to do with rumors and stories containing such basic contradictions in terms of chronology and content? In the case of the al-Battūrī library, oral accounts remain almost the sole evidence through which to understand the history of this library's destruction. Regarding the inconsistencies in chronology, White (2000, pp. 38-39) pointed out that "historians routinely mediate between different accounts of the same event; why should this mediation be methodologically any different when the different accounts are provided by one person?" In terms of context and circulation, as with accounts of vampirism in East Africa, rumors and secrets relating to manuscript libraries in Jerba must fall into the space between the everyday and the outrageous. To borrow terms from Brennan and Dingley, the spread of these stories ultimately hinges on the "explanatory context" and the "constellation" of who heard the stories, how they chose to respond to them, and the expectations of the audience. As with gossip, disease, and even fictional zombie outbreaks (Amaral \& Arenzon, 2018), levels of resistance to the spread of stories and rumors about manuscripts in Jerba vary considerably. A story in which an obscure book collection was dispersed gradually through family inheritance-a very common fate for the history of manuscript collections in Jerba-does not achieve wide circulation. By contrast, when the stories offer something new and scandalous (White, 1994), as in the case of the account of the intentional burning of a well-known collection (or the fabrication of such a story because the family has something to hide), they circulate much more widely.

\section{2 | Stealing books (?): The al-Bārūnī library}

Unlike the al-Ba'țūrī collection, the al-Bārūniyya (El Barounia) library remains very much intact. Located in the town of Houmt Souk, it is the highest profile Ibadi manuscript collection on the island. In this case, rumor and uncertainty overshadow not the details of the library's destruction but the circumstances of its constitution. The methodological issue raised by the history of the al-Bārūnī library stems not from competing oral accounts but inconsistencies in written accounts, some of which differ markedly from oral tradition in the family.

The al-Bārūnī family narrative of the collection's history traces the library's founding to Sa'îd b. 'T̃sā al-Bārūnī (d.1868). Originally from the Jebel Nafusa in northwestern Libya, Sa îd traveled as a young man to Cairo for study, 
where he remained for several years copying and collecting manuscripts. He later returned to the Jebel Nafusa, where he acquired other manuscripts from a relative. From there he moved to the nearby island of Jerba, where he took up the post of Imam at the island's Great Mosque. A key element of this version of events suggests that the al-Bārūnī library eventually absorbed the manuscripts in the Great Mosque's library. The resulting collection contains some 1000 volumes, containing many more titles (al-Bārūnī, 1998; "Fihris," 2018, pp. 3-13).

Several attempts have been made to catalog the collection over the past several decades. Inventories or partial catalogs were prepared in the 1960s, 1980s, and 1990s (al-Bārūnī, 1998; "Qā’imat al-kutub," 1987, pp. 6-14). Most recently, a team of researchers from the Mzab valley in Algeria arrived in Jerba in 2014 to begin a full catalog of the Ibadi titles in the al-Bārūni library ("Fihris," 2018). In the introduction to the catalog, they included a biography of the library's founder and a history of the collection based on letters and family documents relating to the library's history. Those documents in some ways challenged the family's version of the collection's origins. In particular, they found almost no evidence of the al-Bārūni library having absorbed the manuscript collection of the Great Mosque ("Fihris," 2018, p. 30). This represented the first fundamental inconsistency in the library history.

The second resulted from a man who visited our EAP project team in 2017 with photocopies of three documents from the Tunisian National Archives. These three, one-page letters of complaint addressed to head of the Tunisian Protectorate's (1881-1956) "Association of Religious Endowments" (Jam iyyat al-awqäf) in January 1895 claimed that the Imam of the Great Mosque, Yūsuf al-Bārūnī (great grandfather of the current curator) had requested the library's key from the Shaykh of the district, Abū Zakarīyā' Būmiswar. Shortly thereafter, al-Bārūnī returned and reported that the library's books were missing. The report carefully clarifies that the Shaykh did not accuse anyone specific of stealing the books (Būmiswar, 1895; "Letters from the Association of Awqāf").

Despite this final detail, members of the EAP team saw these documents as potentially incriminating to the history of the family and the library's collection. In their view, producing documents that suggested an alternative version of the library's (i.e., the family's) history-especially one that could be misunderstood as an accusation of theft-might lead the family to restrict access to the collection. The EAP team and others present to hear the story deemed these documents too dangerous to reveal. Moreover, the photos were of poor quality and did not contain references to the archival folder numbers, preventing us from verifying their authenticity. Only 2 years later during fieldwork in the Tunisian National Archives did I find the original documents.

In this case, the methodological problem stems from the inconsistencies among oral tradition in the family, the written sources in the library, and the evidence from the National Archives. Drawing on White's analysis of vampires, this tension between written and oral could be recast as complementary. In reality, a careful comparison on these types of sources does not result in much inconsistency. The family's oral tradition of the manuscripts from the Great Mosque's library having been absorbed into the al-Bārūnī library does differ from the written report by the library's catalogers, but only in the absence of direct evidence. The three 19th-century documents, despite carrying as they do the perceived power of the archives, do not directly incriminate the family's history or the library's origins. Quite the opposite: the documents specifically note that no one was accused of the theft. Just as White described the interplay of newspaper reports and discussions among locals in the abduction trial of Juma Kasolo mentioned above, it was only the "feedback" between the oral and written accounts that produced the apprehension felt by the EAP team. The danger they perceived in discussing the option of revealing the written account-not the written account on its own-prevented them from revealing it to the family. As for the documents and the account of the theft they describe, those likely point to some element in the past or present of the library-some part of its historical constellation-that if identified would help explain this anxiety over the documents.

\section{3 | Concealing books (?): The Sālim b. Ya'qūb library}

The library of the Bin Yaquăb family raises methodological issues that are quite different from the previous two collections. Although like the al-Bārūnī library it remains intact, the collection resembles the al-Ba'țūrī library in its 
inaccessibility-not from its having been destroyed but from the choice of the library's owners to prevent most researchers from accessing it. The methodological challenge it presents is twofold. First and foremost, of course, is that access to the collection is restricted and so some valuable sources known to be in the collection cannot be accessed. Second-and more fundamental-is what to do with facsimiles of sources that are allegedly from the collection but whose origin cannot be verified.

The origins of the library's collection owe themselves entirely to the efforts of one man: the library's founder, Shaykh Sālim b. Ya'qūb (d.1991). From Jerba, he traveled to Tunis to attend courses at the Zaytuna Mosque and then to Cairo in late 1933. Over the course of his 5 years in Egypt, he collected hundreds of manuscript fragments relating to Ibadi history. When he returned to Jerba in 1939, he had gathered an impressive collection of manuscript materials that soon gained a reputation as one of the most important lbadi libraries in the Maghrib (al-Būjdīdī, 2012; Bābā'ammī, 2000, pp. 167-68).

Later in his life, Shaykh Sālim's manuscript collection attracted the attention of many researchers and students from Tunisia and abroad. Since his death in 1991, however, researchers have had virtually no way of knowing the precise contents of the library because collection has been inaccessible and no published inventory exists from lifetime of the founder. References to documents and photographs from the collection have regularly appeared in the footnotes of publications, suggesting that several of his students have photographs or photocopies of manuscripts (e.g., Djaabiri, 1975; Muṣlị, 2012). In addition, foreign researchers who visited the library in Shaykh Sālim's lifetime also took a number of photographs. For the most part, however, the contents of the library remained unknown until quite recently.

This changed as a result of two events. As for the first, a prominent rumor claims that a group of foreign researchers came to the Bin Ya'qūb family in the 2000s and paid for access to photograph part of the collection. Appearing to confirm the rumor, photographs of manuscripts allegedly from the library have circulated among researchers. Unfortunately, they only include the manuscripts collected by Shaykh Sālim and none of the dozens of notebooks and other manuscripts in his own hand.

In 2015, unaware of these photographs, I collaborated with the Bin Yaqūb family to document and conserve the library by compiling an inventory of its contents. Aided by a grant from The Islamic Manuscripts Association (TIMA), I worked with the family to inventory the manuscript fragments in the collection and provided them acid-free archival boxes and a shelving unit for their storage. I was expressly forbidden from working on the collection inside the library. Instead, we relocated the manuscripts in cardboard boxes in the back seat of a taxi to the salon of a dental clinic in downtown Houmt Souk. These comprised, I later discovered, the same manuscripts that had already been photographed (Love, 2017). A few months later, I returned to Jerba to place the fragments in their folders and boxes. When we began the EAP project in 2017 , I was informed by colleagues that they had recently seen those same fragments-no longer in the boxes or in the order I inventoried them.

Unable now to access the collection again, I cannot confirm whether that indeed has happened. Additional rumors about the family's desire to monetize the collection have earned it a dubious reputation. I was told with certainty by colleagues this was the "real" reason for the owner having cooperated with me and for his not having told me about the previous project. A troubling rumor from my fieldwork in 2019 claimed that the family had recently sold manuscripts from the library (not facsimiles of them) to a foreign buyer.

The inability to access the collection or verify its contents creates two interrelated methodological challenges. First, the library's inaccessibility of course means that the contents cannot be examined for use in research. Given that the library is, after all, the private property of the family, access remains the prerogative of the owners. The second and more problematic issue, however, is that many images of texts allegedly from the library have circulated widely. The inaccessibility of the collection means that the authenticity of these documents, although likely, remains uncertain. In this way, the digital facsimiles of documents from the library resemble the oral traditions or rumored histories of the other two collections.

Here again, perhaps histories of vampires can help. Vampires (probably) do not exist at all and yet this has not prevented historians for writing about them. The Bin Ya'qūb collection neatly combines the issues of the previous 
two libraries in that it requires that historians consider the both the historical and contemporary contextual explanations for all the secrecy and rumors surrounding its recent history. Whether about libraries or otherwise, families may often have very good reasons for keeping secrets and trying to understand why could prove a fruitful exercise, as it has been in very different contexts (Cohen, 2017; Stein, 2019, pp. 170-177). At the same time, however, it is not that these manuscripts no longer exist or that the origins of their presence in the library are unclear. Instead, the problem lies in the manuscripts only being accessible in facsimiles, the origins of which are unverifiable.

\section{CONCLUSION}

The rumors and stories that belong to the histories of manuscript libraries in Jerba clearly differ from fantastical accounts of vampires in early 20th century East Africa. What I have suggested here is not a copy-paste methodology from one historical context to another. Rather, I propose that by taking the basic premise of historians approaching vampire stories-that regardless of inconsistencies and contradictions in terms of their details, chronology, or even veracity, rumors and other unverifiable stories carry value for understanding the past-these studies are helpful in thinking through some basic problems of historical research, including the far more mundane history of libraries.

The case of the al-Ba'tūiri library raised two essential problems of historical narrative: chronology and facts. While a careful comparison of oral accounts and written evidence could lead to at least an approximate date for the event of the fire, the latter issue presents a more serious challenge. Understanding why some people on the island would deny that the fire occurred at all challenges us to think about what in the historical constellation of the island might help explain such a basic contradiction of accounts. By contrast, the history of the al-Bārūni library demonstrated that historical evidence that might initially appear contradictory may only seem so because of the explanatory context of its interpretation in the present. Only the fear that the family would read the archival documents as an accusation of book theft suggested an inconsistency in its historical narrative. Like the denial of the fire that destroyed the al-Ba țūrī library, however, the potency of this fear demands further explanation, as well. Finally, the story of the Bin Ya'qūb library raised questions of access to evidence and its authenticity. Without access to the library, historians cannot be certain of its contents but in some cases facsimiles of manuscripts and documents from the collection have circulated among researchers. However, these facsimiles present the more basic problem of authenticity. The context of the library and its inaccessibility heighten our awareness of the uncertainty of the items' authenticity in a way that many historians would not question in other circumstances, such as a facsimile of an archival document with its inventory number neatly labeled in the corner of the page.

For each of these manuscript library histories, approaches developed by historians working with accounts of vampirism offer methodological opportunities for recasting these inconsistences and contradictions as entry points to unexpected lines of inquiry and novel, creative uses of historical evidence.

\section{ACKNOWLEDGEMENTS}

Fieldwork for this article was carried out sporadically over a period of several years. Fieldwork in 2015 was under the auspices of a Collection Care and Emergency Response Grant from The Islamic Manuscripts Association (TIMA). I gathered additional information during fieldwork made possible by two separate grants from the Endangered Archives Programme, funded by the Arcadia Fund and administered by the British Library (EAP993, Pilot Grant in 2017-2018; EAP1216, Major Project Grant 2019-2021). I wish to thank those in Jerba and Tunis who helped compile the information presented here including Ali Boujdidi, Mahfoudh Ben Dahman, Laroussi Khemira, Neji Ben Yaagoub, Sassi Ben Yahyaten, Said El Barouni, Farid El Cadhi, Hussein Kharroubi, Ahmad Moslah, and Zouheir Tighlet. Many additional thanks to Derek Elliott, Joel Gordon, and Soufien Mestaoui for reading and commenting on different versions of the article. Emma Park, who generously read and commented on earlier versions, also deserves special thanks for initially suggesting I think with vampires. Elements of the stories offered here were presented at the Al Akhawayn University Faculty Brown Bag Series and the Seminar on the Care and the Conservation of 
Manuscripts at the University of Copenhagen in 2018, where I received valuable feedback. A very different version was also workshopped with undergraduate students enrolled in the Al Akhawayn University Honors Seminar in Spring 2018. I would like to thank them sincerely for their suggestions, critiques, and enthusiasm.

\section{ORCID}

Paul M. Love Jr. (D) https://orcid.org/0000-0001-8977-3496

\section{ENDNOTES}

${ }^{1}$ On these projects, see: "Conserving Endangered Family Manuscript Libraries on the Island of Jerba, Tunisia (EAP993)", online at: https://eap.bl.uk/project/EAP993; "The Jerba Libraries Project: Preserving Endangered Manuscripts and Early Arabic Print Materials in Private Libraries in Jerba, Tunisia (EAP1216)", online at: https://eap.bl.uk/project/EAP1216.

2 Unfortunately, members of the al-Bațūī family declined to speak with me about the history of the collection. The details of other interviews with people connected to the library will be discussed in a photo essay by the author (forthcoming).

\section{REFERENCES}

al-Bārūnī, S., (1998). Fihris makhțūțāt maktabat al-Bārūnī bi-Jarba. Tunis: [N.P].

al-Būjdīdī, A. (2012). al-Shaykh Sālim b. Ya qūb: ḥayāt rajul wa-tajribat jīl. Majallat al-ḥayāt, 12, 170-182.

al-Ibāḍī, I. S. (1986). In W. Schwartz, \& S. B. Ya'qūb (Eds.), Kitāb fīhi bad' al-islām wa-sharāi' al-dīn. Dār al-șāḍir.

Amaral, M. A., \& Arenzon, J. J. (2018). Rumor propagation meets skepticism: A parallel with zombies. Europhysics Letters, 124(1), 18007. https://doi.org/10.1209/0295-5075/124/18007

Anonymous (1987). Qāiimat al-kutub al-mawjūda fĩ'l-maktabāt al-khāșșa wa-'I-āmma. Hūmat al-sūq: Jam iyyat șiyānat jazīrat Jarba.

Anonymous (2018). Fihris makhțūțāt al-maktaba al-Bārūniyya bi-Jarba. Jamìyyat Abī Isḥāq Ițfayyish.

Bābā'ammī, M. S. N. (Ed.) (2000). Mujam a'lām al-ibāḍiyya (Dictionnaire des hommes illustres de l'lbadisme, les hommes du Maghreb) (Vol. 2). Dār al-Gharb al-Islāmī: Beirut.

Bayly, C. A. (1999). Empire and information: Intelligence gathering and social communication in India, 1780-1870. Cambridge University Press.

Brennan, J. R. (2008). Destroying Mumiani: Cause, context, and violence in Late Colonial Dar Es Salaam. Journal of Eastern Africa Studies, 2(1), 95-111. https://doi.org/10.1080/17531050701847276

Būmiswar, A. (2 January, 1895; 12 January 1895; 17 January 1895). Letters from the Association of Awqāf (Jerba office) to the head of the Association of the Awqāf, Muhammad Șafr. (C1 0001000140003 ) Archives nationales de Tunisie.

Choudhury, D. K. L. (2004). Sinews of panic and the nerves of empire: The imagined state's entanglement with information panic, India c.1880-1912. Modern Asian Studies, 38(4), 965-1002. https://doi.org/10.1017/S0026749X0400126X

Coast, D., \& Fox, J. (2015). Rumour and politics. History Compass, 13(5), 222-234. https://doi.org/10.1111/hic3.12234

Cohen, D. (2017). Family secrets: Shame and privacy in Modern Britain. Oxford University Press.

Dingley, Z. (2018). Rumor and history revisited: 'Mumiani' in Coastal Kenya, 1945. The Journal of African History, 59(3), 381-398. https://doi.org/10.1017/S0021853718000749

Djaabiri, F. (1975). Niẓām al-'azzāba ind al-ibạ̣̄iyya bi-Jarba (L'Organisation des azzaba chez les ibadhites de Jerba). Institut National d'Archéologie et d'Art.

Ennami, A. K. (1970). A description of new Ibadi manuscripts from North Africa. Journal of Semitic Studies, 15(1), 63-87. https://doi.org/10.1093/jss/15.1.63

Fischer-Tiné, H., \& Whyte, C. (2017). Anxieties, fear and panic in colonial settings empires on the verge of a nervous breakdown. Palgrave Macmillan.

Gaiser, A. (2010). Muslims, scholars, soldiers: The origins and elaboration of the Ibāḍi Imamate traditions. Oxford University Press.

Ghosh, A. (2008). The role of rumour in history writing. History Compass, 6(5), 1235-1243. https://doi.org/10.1111/j.14780542.2008.00552.x

Hoffman, V. J. (2012). The essentials of Ibādīi Islam. Syracuse University Press.

Hoffman, V. J. (2015). Ibāḍism: History, doctrines, and recent scholarship. Religion Compass Religion Compass, 9(9), $297-307$. https://doi.org/10.1111/rec3.12164

Love, P. M. Jr. (2017). The Sālim b. Ya'qūb Ibāḍī Manuscript Library in Jerba, Tunisia: A Preliminary Survey \& Inventory. Journal of Islamic Manuscripts, 8, 257-280.

Love, P. M. Jr. (2018). Ibadi Muslims of North Africa: Manuscripts, mobilization, and the making of a written tradition. Cambridge University Press. 
Mann, G. (2008). An Africanist's apostasy: On Luise White's 'Speaking with Vampires.'. The International Journal of African Historical Studies, 41(1), 117-121.

Muṣliḥ, A. (2012). al-Waqf al-jarbī fĩ Miṣr wa-dawruhu fíl-tanmiya al-iqtișādiyya wa-'l-ijtimāìyya wa-'I-thaqāfiyya min al-qarn al-'āshir ilāll-qarn al-rābi' 'ashar al-hijrīyayn (Wikālat al-Jāmūs namūdhajan). Kuwait: al-Amāna al-'Āmma lil-Awqāf.

Pels, P. (1992). Mumiani: The white vampire: A neo-diffusionist analysis of rumour. Etnofoor, 5(1-2), 165-187.

Pettigrew, E. (2016). The heart of the matter: Interpreting bloodsucking accusations in Mauritania. The Journal of African History, 57(03), 417-435. https://doi.org/10.1017/S0021853716000323

Stein, S. A. (2019). Family papers: A Sephardic journey through the twentieth century. Farrar, Straus and Giroux.

White, L. (1993). Vampire priests of Central Africa: African debates about labour and religion in Colonial Northern Zambia. Comparative Studies in Society and History, 34(4), 744-770.

White, L. (1994). Between Gluckman and Foucault: Historicizing rumor and gossip. Social Dynamics, 20(1), 75-92. https:// doi.org/10.1080/02533959408458562

White, L. (1997). Cars out of place: Vampires, technology, and labor in East and Central Africa. In F. Cooper, \& A. L. Stoler (Eds.), Tensions of empire (pp. 436-460). University of California Press.

White, L. (2000). Speaking with vampires: Rumor and history in colonial Africa. University of California Press. https://doi.org/ $10.1525 / 9780520922297$

Wilkinson, J. (2010). Ibādism: Origins and early development in Oman. Oxford University Press.

\section{AUTHOR BIOGRAPHY}

Paul M. Love Jr. is an assistant professor of North African, Middle Eastern, and Islamic history at Al Akhawayn University in Ifrane, Morocco. He holds a Ph.D. from the University of Michigan-Ann Arbor (2016). His research focuses on the history of Ibadi Muslim communities in northern Africa and the Arabic Islamic manuscript traditions of the Maghrib. For more on his research, see his website at: http://www.ibadistudies.com.

How to cite this article: Love PM Jr. Manuscripts are like vampires: Libraries and their uncertain histories on the island of Jerba, Tunisia. History Compass. 2020;e12626. https://doi.org/10.1111/hic3.12626 